\title{
Classification of Herbal Drug Effects by Discriminant Analysis of Quantitative Human EEG Data
}

\author{
Wilfried Dimpfel \\ Justus-Liebig-University Giessen c/o NeuroCode AG, Wetzlar, Germany \\ Email: dimpfel1945@web.de
}

How to cite this paper: Dimpfel, W. (2019) Classification of Herbal Drug Effects by Discriminant Analysis of Quantitative Human EEG Data. Neuroscience \& Medicine, 10, 101-117.

https://doi.org/10.4236/nm.2019.102007

Received: March 27, 2019

Accepted: May 24, 2019

Published: May 27, 2019

Copyright $\odot 2019$ by author(s) and Scientific Research Publishing Inc. This work is licensed under the Creative Commons Attribution International License (CC BY 4.0).

http://creativecommons.org/licenses/by/4.0/

\section{cc) (7) Open Access}

\begin{abstract}
Clinical indications for herbal drugs very often only rely on traditional knowledge. Single plant-derived preparations are used for many purposes and cannot be classified to belong to a single category like calming or stimulating drugs. With respect to the brain a unique possibility exists to analyze drug effects by recording the EEG. It is common knowledge that many drugs change the frequency content of electric brain activity. Quantitative analysis of the EEG by Fast Fourier Transformation reveals parameters like spectral power, which can be processed further $\left(\right.$ CATEEM $\left.^{\circledR}\right)$. Source density was determined from 17 channels of the quantitative EEG from 10 clinical studies recorded in a relaxed state with open eyes. Linear discriminant analysis was used to differentiate the effects of Placebo (circadian rhythm) from CNS-active herbal drugs in comparison to Valium ${ }^{\circledR}$. Calmvalera ${ }^{\circledR}$, L-Theanine, Lasea ${ }^{\circledR}$, Neurapas $^{\circledR}$, Neuravena ${ }^{\circledR}$, Neurexan $^{\circledR}$, Nutrifin Relax ${ }^{\circledR}$, Pascoflair ${ }^{\circledR}$ (herbal calming drugs) as well as memoLoges ${ }^{\circledR}$, Zembrin ${ }^{\circledR}$ (herbal stimulating drugs) induced different changes of the frequency content of brain electric activity. Discriminant analysis revealed that Nutrifin Relax ${ }^{\circledR}$, Pascoflair ${ }^{\circledR}$ and Suntheanine ${ }^{\circledR}$ could not be separated well from each other indicating a similar mechanism of action. The effect of Valium ${ }^{\circledR}$ was projected at a very isolated position far away from the herbal preparations indicating a totally different mechanism of action. Zembrin ${ }^{\circledR}$ and memoLoges ${ }^{\circledR}$ grouped together with respect to the first three discriminant functions, but were different with respect to the $4^{\text {th }}$ to $6^{\text {th }}$ discriminant function. Lasea $^{\circledR}$ as anxiolytic drug and Neurapas ${ }^{\circledR}$ as antidepressive drug were projected at isolated positions indicating their different clinical indications. The results indicate that discriminant analysis of human quantitative EEG data allows for unique pharmacological description of individual effect profiles of herbal drugs.
\end{abstract}




\section{Keywords}

Quantitative EEG, Discriminant Analysis, Herbal Drugs, Fast Fourier Transformation, Central Nervous System, CATEEM

\section{Introduction}

Widespread clinical use of behavior-modifying drugs having defined biochemical actions has provided observations and generated hypotheses that relate neurochemical findings to normal and abnormal behaviors in man [1]. Since many drugs act on the central nervous system by interference with neurochemical processes leading to changes of electric activity, measurement of the electric activity of the brain is a very promising approach to characterize the effectiveness of drugs acting on the central nervous system [2]. To characterize and classify pharmacological effects of herbal drugs on the brain remains a major challenge. Within clinical studies many different parameters can be measured like filling out questionnaires, psychometric testing or collecting neurophysiological parameters like ECG and EEG.

In day-night converted rats recording of field potentials from the depth of the brain revealed significant changes in the presence of drugs in comparison to placebo. Quantitative analysis of these data by frequency analysis using Fast Fourier Transformation (FFT) documented time and dose dependent changes of spectral power in four brain areas (frontal brain, hippocampus, striatum and reticular formation). Results from frequency analysis were documented according to 6 specifically defined ranges (frequency bands). In order to discriminate effects of 40 drugs with known clinical indications from each other, 24 parameters (spectral power from 4 brain areas $\times 6$ frequency bands) were fed into linear discriminant analysis. Surprisingly, drugs with similar indication clustered together (could not be discriminated well from each other) and were clearly separated from drugs with other indications [3]. The question now arose, if also quantitative human EEG data could serve to separate drug effects from each other. Therefore data from several clinical studies, which had been performed at NeuroCode AG in the past, were re-analyzed. In this case 102 parameters (spectral power from 17 brain areas $\times 6$ frequency bands) were fed into discriminant analysis. As will be shown below, also human quantitative EEG data allow separation of effects from each other and comparison of the effects of drugs acting on the central nervous system in an analog manner i.e. drugs with a similar indication group together whereas others are well separated from each other. Thus, discriminant analysis allows for documentation of their unique pharmacological action also in humans. This leads to a direct comparison and a new method for classification of herbal drugs in humans.

\section{Material and Method}

Data from 10 clinical studies were reanalyzed. Quantitative EEG data were ob- 
tained by Fast Fourier Transformation of analog data [4]. Data were calculated as "source density" corresponding to magnet-encephalographic analysis [5] [6]. The resulting frequency spectra were cut into six frequency bands: delta: 1.25 $4.5 \mathrm{~Hz}$; theta: 4.75 - $6.75 \mathrm{~Hz}$; alpha1: 7.0 - $9.5 \mathrm{~Hz}$; alpha2: 9.75 - $12.5 \mathrm{~Hz}$; beta1: 12.75 - $18.5 \mathrm{~Hz}$; beta2: 18.75 - $35.0 \mathrm{~Hz}$. Spectral power obtained in a relaxed state with open eyes in the presence of drugs was compared to placebo at 17 electrode positions corresponding to 17 brain areas. Technology CATEEM $\left.^{(}\right)$from MEWICON CATEEM-Tec GmbH, Schwarzenberg, Austria was used.

All experiments were performed under identical conditions as published earlier [7]. In short: EEG was recorded for 5 minutes from subjects in a relaxed state before intake of the particular drug. Up to three hours later (as indicated individually for each drug) this procedure was repeated and the result compared to the baseline recording in terms of spectral power changes in 6 frequency ranges at all brain regions. Brain maps were constructed by transforming spectral power into spectral colours followed by additive colour mixture according to "RGB" [8]. Data were statistically compared to the spectral changes as observed under the corresponding placebo condition (representing the circadian rhythm) using the non-parametric Wilcoxon-Mann-Whitney Test. Finally, all 102 parameters were fed into discriminant analysis and documented as 6 dimensional display (results from the first 3 discriminant functions were displayed in space, result of next 3 functions into colour using the RGB mode of additive colour mixture). Detailed information on the drugs is given in Table 1 and Table 2.

\section{Results}

\subsection{Circadian Rhythm}

Electric activity of the human brain changes with time and follows a circadian rhythm [9]. Thus, during the 3 hours between baseline recording and the second recording spectral power has changed. This is documented as average spectral power in 148 subjects collected from 10 studies in Figure 1. Mainly alpha spectral power increases in nearly all brain areas. But also beta power increases in several brain areas. Therefore, spectral power changes induced in the presence of drugs have to be compared to this pattern statistically.

\subsection{Calmvalera ${ }^{\circledR}$ Tablets}

Calmvalera ${ }^{\circledR}$ tablets are prescribed for nervous restlessness and better coping with stress. This homeopathic remedy has been tested within a clinical study in young subjects suffering from examination anxiety. Clinical efficacy was demonstrated [10]. Statistically significant spectral power changes with respect to alpha waves in the presence of 6 tablets Calmvalera ${ }^{\circledR}$ were mainly confined to the left hemisphere as indicated by uneven numbers of electrode positions $\left(\mathrm{F}_{3}, \mathrm{C}_{3}, \mathrm{P}_{3}, \mathrm{~T}_{3}, \mathrm{O}_{1}\right)$. Increases of alpha and betal waves were statistically significantly different from spectral changes due to the circadian rhythm. Further details are given in Figure 2. 
Table 1. Drugs with ingredients and given dosages.

\begin{tabular}{|c|c|c|}
\hline & Ingredients & Dosage \\
\hline Calmvalera $^{\circledR}$ & $\begin{array}{l}\text { Cimicifuga Trit. D3 } 20 \mathrm{mg} \text {, Cocculus Trit. D4 } 20 \mathrm{mg} \\
\text { Cypripedium pubescens Trit. D4 } 10 \mathrm{mg} \text {, Ignatia Trit. D6 } 40 \mathrm{mg} \\
\text { Lilium tigrinum Trit. D6 } 20 \mathrm{mg} \text {, Passiflora incarnata Trit. D3 } 40 \mathrm{mg} \\
\text { Platinum metallicum Trit. D8 } 20 \mathrm{mg} \text {, Valeriana Trit. D2 } 20 \mathrm{mg} \\
\text { Zincum valerianicum Trit. D3 } 20 \mathrm{mg} \\
\text { Other ingredients: lactose-monohydrate ( } 35 \mathrm{mg} \text { ), } \\
\text { magnesium stearate (Ph.Eur.), corn starch }\end{array}$ & 6 tab. \\
\hline Lasea ${ }^{\circledR}$ & $\begin{array}{l}\text { Lavender oil } 80 \mathrm{mg} \\
\text { Gelatin polysuccinate } \\
\text { Glycerol } 85 \% \\
\text { Rapeseed oil, refined sorbitol } \\
\text { Carminic acid, aluminum salts } \\
\text { Patent Blue V, aluminum salt } \\
\text { Titanium dioxide }\end{array}$ & 2 cap. \\
\hline memoLoges ${ }^{\circledR}$ & $\begin{array}{l}120 \mathrm{mg} \text { Bacopa monnieri extract }+380 \mathrm{mg} \text { Sideritis scardica extract } \\
\text { plus } 20 \mathrm{mg} \text { of vitamin B6, } 500 \mu \mathrm{g} \text { of Vitamin B12, } 400 \mu \mathrm{g} \text { of folic acid, } \\
18 \mathrm{mg} \text { of Vitamin B5 and } 1.5 \mathrm{mg} \text { of Zinc }\end{array}$ & 2 cap. \\
\hline $\begin{array}{l}\text { Neurapas } \\
\text { balance }\end{array}$ & $\begin{array}{l}\text { Passionflower herb dry extract }(6.2-7.1: 1) 32 \mathrm{mg} \text { native extract } \\
\text { Extraction Agent: Ethanol } 60 \%(\mathrm{~m} / \mathrm{m}) \text { equivalent to } 68 \%(\mathrm{v} / \mathrm{v}) \\
\text { Valerian root dry extract }(3.8-5.6: 1) 28 \mathrm{mg} \text { native extract } \\
\text { Extraction Agent: Ethanol } 40 \%(\mathrm{~m} / \mathrm{m}) \text { equivalent to } 48 \%(\mathrm{v} / \mathrm{v}) \\
\text { The extracts used are extract preparations of native extract and excipients } \\
\text { St. John's wort dry extract preparation }(80 \mathrm{mg} / \text { day): } \\
\text { (75\% native extract }+5 \% \text { silica, colloidal anhydrous }+20 \% \text { lactose monohydrate) } \\
\text { Passionflower herb dry extract preparation ( } 40 \mathrm{mg} / \text { tablet): } \\
\text { (80\% native extract }+20 \% \text { maltodextrin) } \\
\text { Valerian Root Dry Extract Preparation }(40 \mathrm{mg} / \text { tablet): } \\
\text { (70\% native extract }+26 \% \text { glucose, spray dried }+4 \% \text { silica, colloidal anhydrous) }\end{array}$ & 6 tab. \\
\hline Neuravena ${ }^{\circledR}$ & $\begin{array}{l}\text { Wild Green Oat Extract } 400 \mathrm{mg}\left(\text { Neuravena }{ }^{\circledR} * \text { Special Extract 3.5:1) 1; Vitamin B6 } 1.5 \mathrm{mg} \text {; }\right. \\
\text { Vitamin B12 } 2.5 \mu \mathrm{g} \text {; Pantothenic acid } 6 \mathrm{mg}\end{array}$ & $2500 \mathrm{mg}$ \\
\hline Neurexan $^{\circledast}$ & $\begin{array}{l}0.6 \mathrm{mg} \text { Dil. D2 Passiflora incarnata } \\
0.6 \mathrm{mg} \text { Dil. D2 Avena sativa } \\
0.6 \mathrm{mg} \text { Dil. D12 Coffea arabica } \\
0.6 \mathrm{mg} \text { Dil. D4 Zincum isovalerianicum } \\
\text { Magnesiumstearat }(1.5 \mathrm{mg}) \text {, Lactose-Monohydrat }(300 \mathrm{mg})\end{array}$ & 4 tab. \\
\hline Nutrifin Relax ${ }^{\circledR}$ & $\begin{array}{l}3 \mathrm{mg} \text { Lavender oil, } 67.5 \mathrm{mg} \text { Lemon balm extract, } \\
11.25 \text { Oat extract and } 11.25 \mathrm{mg} \text { Hops extract }\end{array}$ & $2 \times 1$ lozenge \\
\hline Pascoflair $^{\circledR}$ & $\begin{array}{l}\text { Passionflower herb dry extract (5-7:1) } 425 \mathrm{mg} \text { native extract } \\
\text { Extraction Agent: Ethanol 50\% (v/v) equivalent to } 42 \%(\mathrm{~m} / \mathrm{m}) \\
\text { The extract used is an extract preparation of native extract and excipients } \\
\text { Passionflower Dried Dry Extract Preparation }(607.1 \mathrm{mg} / \mathrm{tablet}): \\
\text { (70\% native extract }+27 \% \text { maltodextrin }+3 \% \text { silica, colloidal anhydrous) }\end{array}$ & 3 tab. \\
\hline Suntheanine $e^{\circledR}$ & L-Theanine & $250 \mathrm{mg}$ \\
\hline Valium $^{\circledR}$ & $\begin{array}{l}\text { Diazepam } 5 \mathrm{mg} \\
\text { magnesium stearate } \\
\text { corn starch } \\
\text { Iron (III) oxide hydrate (E 172) } \\
\text { Lactose monohydrate }\end{array}$ & $5 \mathrm{mg}$ \\
\hline Zembrin $^{\circledR}$ & $\begin{array}{l}25 \mathrm{mg} \mathrm{Zembrin}^{\circledR} \text { (Sceletium tortuosum extract), microcrystalline cellulose, cellulose (capsule), } \\
\text { silicon dioxide, magnesium stearate }\end{array}$ & $50 \mathrm{mg}$ \\
\hline
\end{tabular}


Table 2. Clinical indications of the drugs investigated in the studies.

\begin{tabular}{|c|c|c|c|c|c|c|}
\hline & Nervous restlessness & Anxiety & Depression & Sleep disorder & Stress & Cognition \\
\hline Calmvalera $^{\circledR}$ & $\mathrm{X}$ & & $\mathrm{X}$ & $\mathrm{X}$ & $\mathrm{X}$ & \\
\hline Lasea $^{\circledR}$ & $\mathrm{X}$ & $\mathrm{X}$ & & $\mathrm{X}$ & $\mathrm{X}$ & \\
\hline memoLoges ${ }^{\circledR}$ & & & & & & $\mathrm{X}$ \\
\hline Neurapas ${ }^{\circledR}$ balance & $\mathrm{X}$ & & $\mathrm{X}$ & & & \\
\hline Neuravena ${ }^{\circledR}$ & & & & & & $\mathrm{X}$ \\
\hline Neurexan $^{\circledR}$ & $\mathrm{X}$ & & & $\mathrm{x}$ & & \\
\hline Nutrifin Relax ${ }^{\mathbb{B}}$ & $\mathrm{X}$ & & & & & \\
\hline Pascoflair $^{\circledR}$ & $\mathrm{X}$ & $\mathrm{X}$ & & & $\mathrm{X}$ & \\
\hline Suntheanine ${ }^{\circledR}$ & $\mathrm{X}$ & & & & & \\
\hline Valium $^{\circledR}$ & $\mathrm{X}$ & $\mathrm{X}$ & & $\mathrm{X}$ & $\mathrm{X}$ & \\
\hline Zembrin $^{\circledR}$ & $\mathrm{X}$ & $\mathrm{X}$ & & & $\mathrm{X}$ & $\mathrm{X}$ \\
\hline
\end{tabular}

\section{Circadian Rhythm}

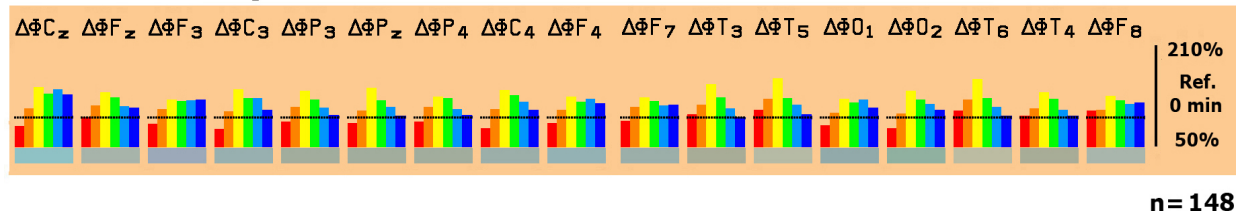

Figure 1. Spectral power changes in \% of the baseline values (Ordinate) according to the circadian rhythm at all electrode positions ( $100 \%$ is indicated by a line). Red: spectral delta power; orange: theta power; yellow: alpha 1 power; green: alpha 2 power; turquoise: beta 1 power and blue: beta 2 power (for frequency band definitions see methods).

\section{Calmvalera $^{\circledR}$}

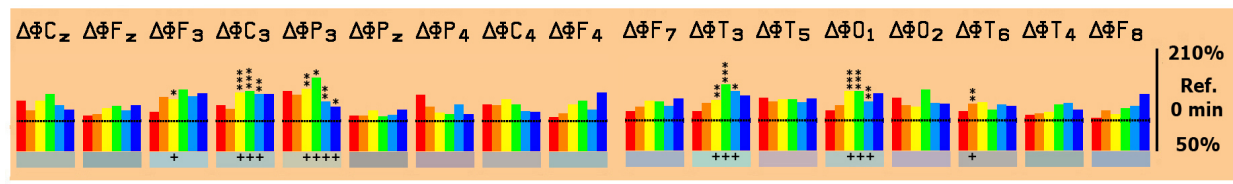

$\mathrm{n}=\mathbf{1 2}$

Figure 2. Spectral power changes in $\%$ of the baseline values in the presence of Calmvalera ${ }^{\circledR}$. Statistical significance in comparison the circadian changes is documented by stars: ${ }^{*} \mathrm{p}<0.1$, ${ }^{* *} \mathrm{p}<0.05,{ }^{* *} \mathrm{p}<0.01$. "+" underneath the bars indicates the direction of spectral changes (increase of spectral power).

\subsection{Lasea ${ }^{\circledR}$}

Lasea ${ }^{\circledR}$ is an herbal drug prescribed to treat general anxiety [11] [12]. Its active ingredient Silexan (special extract of lavender oil) has been positively tested for cerebral bioavailability [13]. Spectral power changes in the presence of 2 capsules Lasea $^{\circledR}$ consisted mainly in significant increases of alpha 1 or alpha2 power in most of the tested brain regions. Strongest increases were observed in central and temporal region as documented in Figure 3. This increase is in line with clinical relaxation. Psychometric testing did not reveal any negative results. 


\subsection{MemoLoges ${ }^{\circledR}$}

MemoLoges ${ }^{\circledR}$ has been clinically tested in subjects suffering from mild cognitive impairment [14] [15]. A dominant feature after intake of 2 capsules memoLog$\mathrm{es}^{\circledR}$ consisted in significant increases of alpha 1 spectral power in most of the brain areas except for the occipital lobe and parts of the frontal lobe (electrode positions $\mathrm{F}_{3}$ and $\mathrm{F}_{4}$ ). For details see Figure 4 .

\subsection{Neurapas ${ }^{\circledR}$}

Neurapas ${ }^{\circledR}$ balance has been developed to fight stress, anxiety and depression. The effect of this drug has been successfully characterized within a clinical study [16]. Intake of 6 tablets Neurapas ${ }^{\circledR}$ balance only led to a few statistically significant changes. In the parietal lobe delta and theta spectral power decreased somewhat, whereas alpha 1 power increased in the temporal lobe. Details are given in Figure 5.

\subsection{Neuravena ${ }^{\circledR}$}

The next herbal drug, which has been analyzed, was Neuravena ${ }^{\circledR}(2500 \mathrm{mg})$.

\section{Lasea ${ }^{\circledR}$}

$\Delta \Phi C_{2} \Delta \Phi F_{2} \quad \Delta \Phi F_{3} \quad \Delta \Phi C_{3} \quad \Delta \Phi P_{3} \Delta \Phi P_{2} \Delta \Phi P_{4} \quad \Delta \Phi C_{4} \quad \Delta \Phi F_{4} \quad \Delta \Phi F_{7} \Delta \Phi T_{3} \Delta \Phi T_{5} \quad \Delta \Phi O_{1} \quad \Delta \Phi O_{2} \quad \Delta \Phi T_{6} \Delta \Phi T_{4} \quad \Delta \Phi F_{8}$

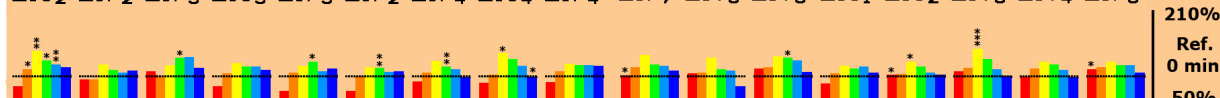

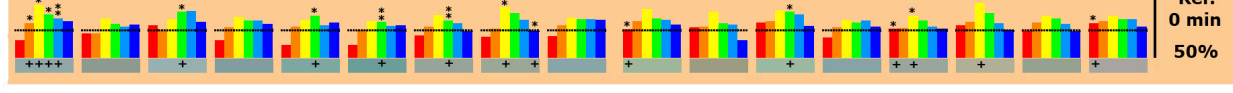

$\mathbf{n}=\mathbf{2 4}$

Figure 3. Spectral power changes in $\%$ of the baseline values in the presence of Lasea ${ }^{\circledR}$. Statistical significance in comparison the circadian changes is documented by stars: ${ }^{\star} \mathrm{p}<0.1,{ }^{* *} \mathrm{p}<0.05,{ }^{* *} \mathrm{p}<$ 0.01. "+" underneath the bars indicates the direction of spectral changes (increase of spectral power).

\section{memoLoges ${ }^{\circledR}$}

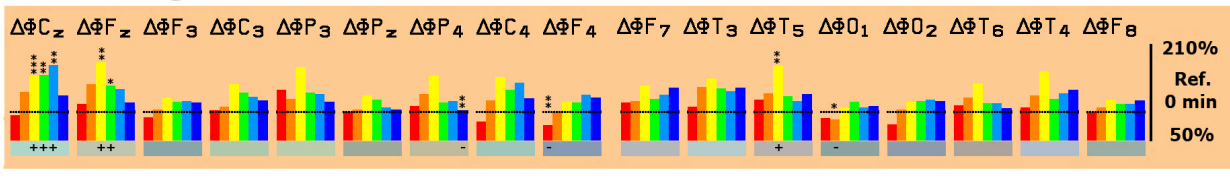

$n=16$

Figure 4. Spectral power changes in $\%$ of the baseline values in the presence of memoLoges ${ }^{\circledR}$. Statistical significance in comparison the circadian changes is documented by stars: ${ }^{*} \mathrm{p}<0.1$, ${ }^{* *} \mathrm{p}<0.05,{ }^{* * *} \mathrm{p}<0.01$. "+" and “-" underneath the bars indicate the direction of spectral changes (increase or decrease of spectral power, respectively).

\section{Neurapas ${ }^{\circledR}$}

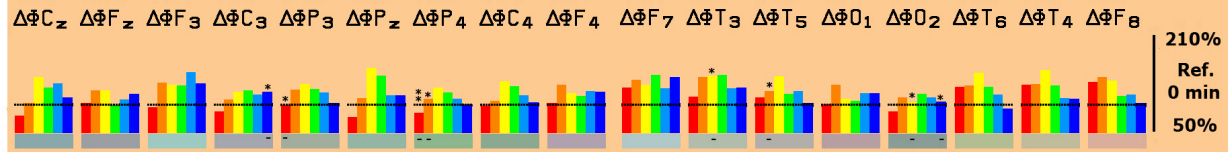

Figure 5. Spectral power changes in $\%$ of the baseline values in the presence of Neurapas ${ }^{\circledR}$ balance. Statistical significance in comparison the circadian changes is documented by stars: ${ }^{*} \mathrm{p}<0.1,{ }^{* *} \mathrm{p}<$ 0.05. "-" underneath the bars indicates the direction of spectral changes (decrease of spectral power). 
This drug has been tested and found to have positive effects on cognition [17] [18]. In comparison to the circadian rhythm increases of alpha1 power dominate this pattern of spectral changes, which, however, only reach statistical significance at electrode positions $\mathrm{P}_{4}$ and $\mathrm{T}_{4}$. Decreases of delta power in many brain regions did not reach statistical significance. All spectral power changes are displayed in Figure 6.

\subsection{Neurexan ${ }^{\circledR}$}

Neurexan ${ }^{\circledR}$ is sold as a homeopathic drug for the treatment of nervousness. A double-blind, randomized clinical trial proved efficacy [19]. A special pattern of spectral changes was observed after intake of 4 tablets Neurexan ${ }^{\circledR}$ since only statistically significant decreases of power dominated the pattern of changes. Most of the changes were confined to alpha waves (Figure 7).

\subsection{Nutrifin Relax ${ }^{\circledR}$}

Another relaxing drug is Nutrifin Relax ${ }^{\circledR}$. EEG was recorded after intake of 2 lozenges. Results have been published earlier [20]. The pattern of alpha power changes is not much different from circadian changes except for left frontal and temporal area (electrode position $\mathrm{F}_{7}$ and $\mathrm{T}_{3}$ ). However, beta 1 power increased statistically significantly at central, frontal and occipital brain regions. Details are given in Figure 8.

\subsection{Pascoflair ${ }^{\circledR}$}

Pascoflair $^{\circledR}$ is used to treat anxiety, nervousness and generalized anxiety disorder. In preoperative surgery patients it reduced anxiety [21]. Its clinical efficacy

\section{Neuravena ${ }^{\circledR}$}

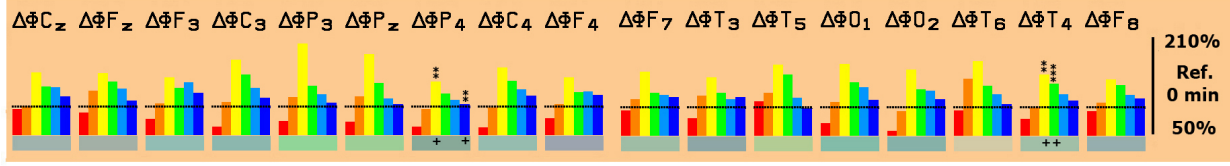

$\mathbf{n}=\mathbf{2 0}$

Figure 6. Spectral power changes in $\%$ of the baseline values in the presence of $2500 \mathrm{mg}$ Neuravena ${ }^{\circledR}$. Statistical significance in comparison to circadian changes is documented by stars: ${ }^{*} \mathrm{p}$ $<0.1,{ }^{* *} \mathrm{p}<0.05,{ }^{* * *} \mathrm{p}<0.01$. "+" underneath the bars indicates the direction of spectral changes (increase of spectral power).

\section{Neurexan ${ }^{\circledR}$}

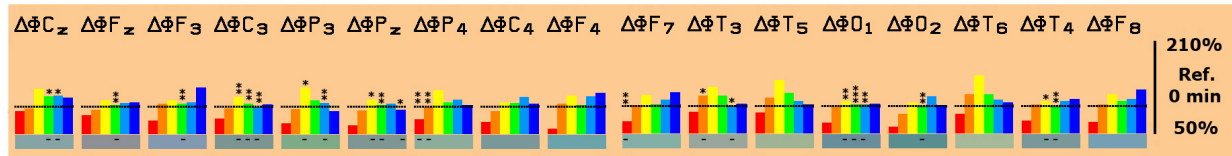

Figure 7. Spectral power changes in $\%$ of the baseline values in the presence of Neurexan ${ }^{\circledR}$. Statistical significance in comparison the circadian changes is documented by stars: ${ }^{*} \mathrm{p}<0.1,{ }^{* *} \mathrm{p}<$ $0.05,{ }^{* * *} \mathrm{p}<0.01$. “-” underneath the bars indicates the direction of spectral changes (decrease of spectral power). 
was also shown by a combination of psychometry and quantitative EEG [22]. Spectral power changes in the presence of 3 tablets Pascoflair ${ }^{\circledR}$ reveal mainly some statistically significant decreases of delta and theta power within the parietal and occipital lobe as depicted in Figure 9. The pattern of alpha power did not differ significantly from the changes as observed according to circadian rhythm.

\subsection{Suntheanine ${ }^{\circledR}$}

An herbal calming drug is Suntheanine ${ }^{\circledR}$. Its active constituent is L-Theanine, a compound found in green tea [23]. The drug is known for its calming properties without producing sedation. In the presence of $250 \mathrm{mg}$ of this preparation only increases of spectral power are observed. Strongest statistically significant effects are seen with respect to alpha power in nearly all brain regions. However, also increases of beta power are observed in some brain areas, which are statistically significant at electrode positions $\mathrm{P}_{3}$ and $\mathrm{O}_{1}$. For details see Figure 10.

\section{Nutrifin Relax ${ }^{\circledR}$}

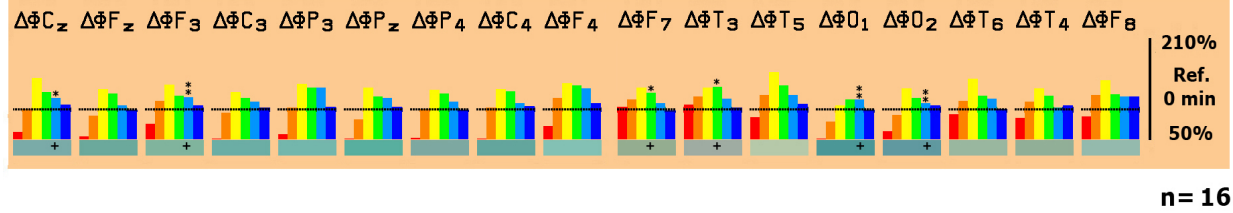

Figure 8. Spectral power changes in $\%$ of the baseline values in the presence of 2 lozenges of Nutrifin Relax ${ }^{\circledR}$. Statistical significance in comparison to circadian changes is documented by stars: ${ }^{\star} \mathrm{p}<0.1,{ }^{* *} \mathrm{p}<0.05$. “+” underneath the bars indicates the direction of spectral changes (increase of spectral power).

\section{Pascoflair ${ }^{\circledR}$}

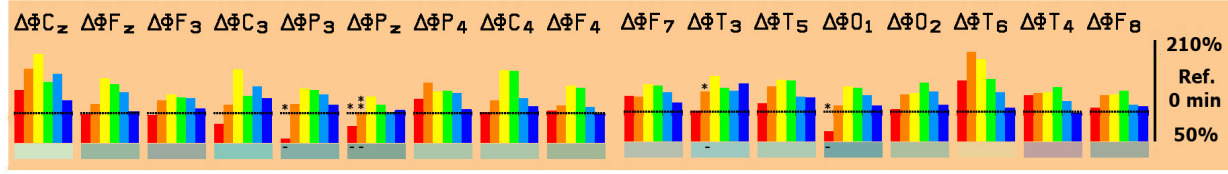

$\mathbf{n}=\mathbf{1 6}$

Figure 9. Spectral power changes in $\%$ of the baseline values in the presence of Pascoflair ${ }^{\circledR}$. Statistical significance in comparison the circadian changes is documented by stars: ${ }^{*} \mathrm{p}<0.1,{ }^{* *} \mathrm{p}<$ $0.05,{ }^{* * *} \mathrm{p}<0.01$. “-” underneath the bars indicates the direction of spectral changes (decrease of spectral power).

\section{Suntheanine ${ }^{\circledR}$}

$\Delta \Phi C_{2} \Delta \Phi F_{2} \Delta \Phi F_{3} \Delta \Phi C_{3} \Delta \Phi P_{3} \Delta \Phi P_{2} \Delta \Phi P_{4} \quad \Delta \Phi C_{4} \quad \Delta \Phi F_{4} \quad \Delta \Phi F_{7} \Delta \Phi T_{3} \Delta \Phi T_{5} \quad \Delta \Phi O_{1} \quad \Delta \Phi D_{2} \quad \Delta \Phi T_{6} \Delta \Phi T_{4} \quad \Delta \Phi F_{8}$

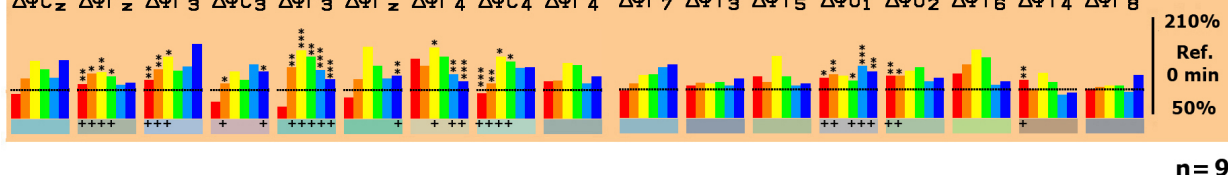

Figure 10. Spectral power changes in \% of the baseline values in the presence of $250 \mathrm{mg}$ Suntheanine ${ }^{\circledR}$. Statistical significance in comparison the circadian changes is documented by stars: ${ }^{*} \mathrm{p}<0.1,{ }^{* *} \mathrm{p}<0.05,{ }^{* * *} \mathrm{p}<0.01$. “+” underneath the bars indicates the direction of spectral changes (increase of spectral power). 


\subsection{Valium ${ }^{\circledR}$}

Valium ${ }^{\circledR}$ is one of the best-known drugs with a strong sedative, anxiolytic and anticonvulsive action [24]. This non-herbal drug (developed in 1963) shows an interesting pattern of spectral changes much different from the circadian rhythm. Theta and alpha frequencies are suppressed in a highly significant manner, whereas spectral beta power has increased in most of the brain areas as documented in Figure 11.

\subsection{Zembrin ${ }^{\circledR}$}

Zembrin $^{\circledR}$ (a special extract of Sceletium tortuosum, which has been consumed by original inhabitants in South Africa for a long time) is a food supplement marketed also in the USA and Canada for improvement of cognitive performance [25] [26]. In the presence of $50 \mathrm{mg}$ Zembrin ${ }^{\circledR}$ increases of alpha 1 spectral power dominated the pattern of changes in a statistically significant manner. Only within the central and parietal area decreases of delta and theta power emerged. For details see Figure 12.

Statistically significant changes of single frequencies in the presence of drugs at any of the brain regions are listed in Table 3. Despite the common indication of calming nervousness (except for Zembrin ${ }^{\circledR}$ and memoLoges ${ }^{\circledR}$ ) there is no common change of frequencies indicating a similar mechanism of action for all these calming drugs. However, there is some similarity between Lasea ${ }^{\circledR}$ and Suntheanine ${ }^{\circledR}$ with regard to the fact, that spectral power of all frequencies increase in a statistically conspicuous or significant manner. This can be interpreted in the sense that single drugs might have additional effects like being able to treat anxiety and/or depression.

\section{Valium ${ }^{\circledR}$}

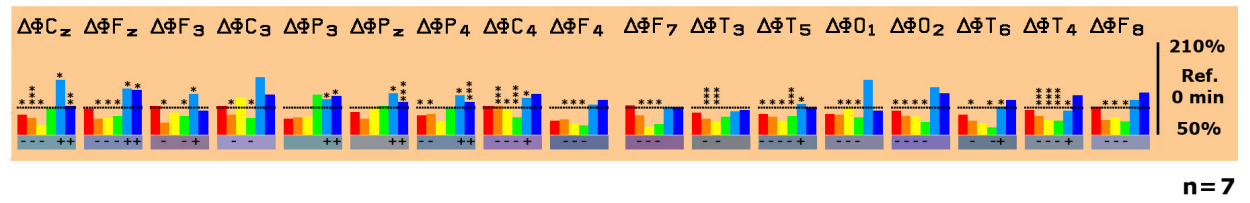

Figure 11. Spectral power changes in \% of the baseline values in the presence of $5 \mathrm{mg}$ Valium ${ }^{\circledR}$. Statistical significance in comparison the circadian changes is documented by stars: ${ }^{\star} \mathrm{p}<0.1$, ${ }^{* *} \mathrm{p}<0.05,{ }^{* *} \mathrm{p}<0.01$. “+” and “-” underneath the bars indicate the direction of spectral changes (increase or decrease of spectral power, respectively).

\section{Zembrin ${ }^{\circledR}$}

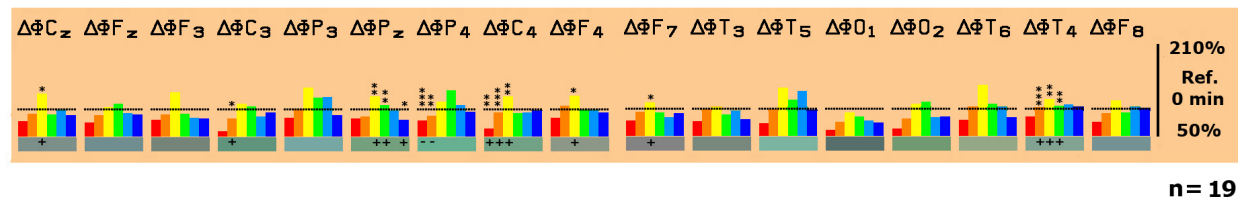

Figure 12. Spectral power changes in $\%$ of the baseline values in the presence of Zembrin ${ }^{\circledR}$. Statistical significance in comparison the circadian changes is documented by stars: ${ }^{\star} \mathrm{p}<0.1$, ${ }^{* *} \mathrm{p}<0.05,{ }^{* *} \mathrm{p}<0.01$. "+” underneath the bars indicates the direction of spectral changes (increase of spectral power). 
Table 3. Listing of statistically significant frequency changes at any of the brain regions.

\begin{tabular}{|c|c|c|c|c|c|c|}
\hline & Delta & Theta & Alpha 1 & Alpha 2 & Beta 1 & Beta 2 \\
\hline Calmvalera $^{\circledR}$ & & + & + & + & + & $(+)$ \\
\hline Lasea $^{\circledR}$ & $(+)$ & $(+)$ & + & + & + & $(+)$ \\
\hline memoLoges $^{\circledR}$ & - & $(-)$ & + & + & + & - \\
\hline Neurapas ${ }^{\circledR}$ balance & - & $(-)$ & $(-)$ & & & $(-)$ \\
\hline Neuravena $^{\circledR}$ & & & + & + & & + \\
\hline Neurexan $^{\circledR}$ & - & - & - & - & - & $(-)$ \\
\hline Nutrifin Relax $^{\circledR}$ & & & & $(+)$ & + & \\
\hline Pascoflair $^{\circledR}$ & $(-)$ & - & & & & \\
\hline Suntheanine ${ }^{\circledR}$ & + & + & + & + & + & + \\
\hline Valium $^{\circledR}$ & $(-)$ & - & - & - & $(+)$ & + \\
\hline Zembrin $^{\circledR}$ & + & + & + & + & & \\
\hline
\end{tabular}

"+” or "-" indicate the direction of changes. Brackets indicate $\mathrm{p}<0.10$, otherwise change of the frequency is statistically significantly different from circadian rhythm at least at the level of $\mathrm{p}<0.05$.

\subsection{Brain Maps}

Another way to document the results from quantitative EEG recording is to construct a brain map. This approach allows an overview on the involvement of different brain regions during the action of drugs. However, there is an influence of the circadian rhythm on electric brain activity during relaxation, which is recognized when placebo is given (Figure 1). These changes are also visible in the brain map in Figure 13. Depending on the action of drugs with respect to different frequencies, colours indicate dominant changes of spectral power. For example, increases of beta 2 waves-like in the presence of Valium ${ }^{\circledR}$-lead to a prevalence of blue colour as depicted in Figure 14. Quantitative EEG maps in the presence of individual drugs differ strongly with respect to change of spectral frequencies as exemplified for all drugs in Figure 13 and Figure 14 for direct comparison.

\subsection{Discriminant Analysis}

The pattern of frequency changes in the brain in the presence of drugs seems to be very specific and can be differentiated from each other by looking at the spectral power in 17 regions. Nevertheless, it would be desirable to find an approach to compress the information for individual characterization and classification of the drug effects. This can be achieved by using discriminant analysis. This type of analysis is based on all 102 parameters (spectral power in 17 brain regions) and separates the effects of all drugs from each other best (Figure 15). This means, that, if drugs are projected in rather close vicinity in space, their action is probably similar. Within the present analysis Nutrifin Relax ${ }^{\circledR}$, Pascoflair ${ }^{\circledR}$ and Suntheanine ${ }^{\mathbb{R}}$ appear in rather close vicinity and all three drugs are prescribed for the same indication: relaxation. However, all calming herbal drugs are positioned 


\section{Eyes Open}

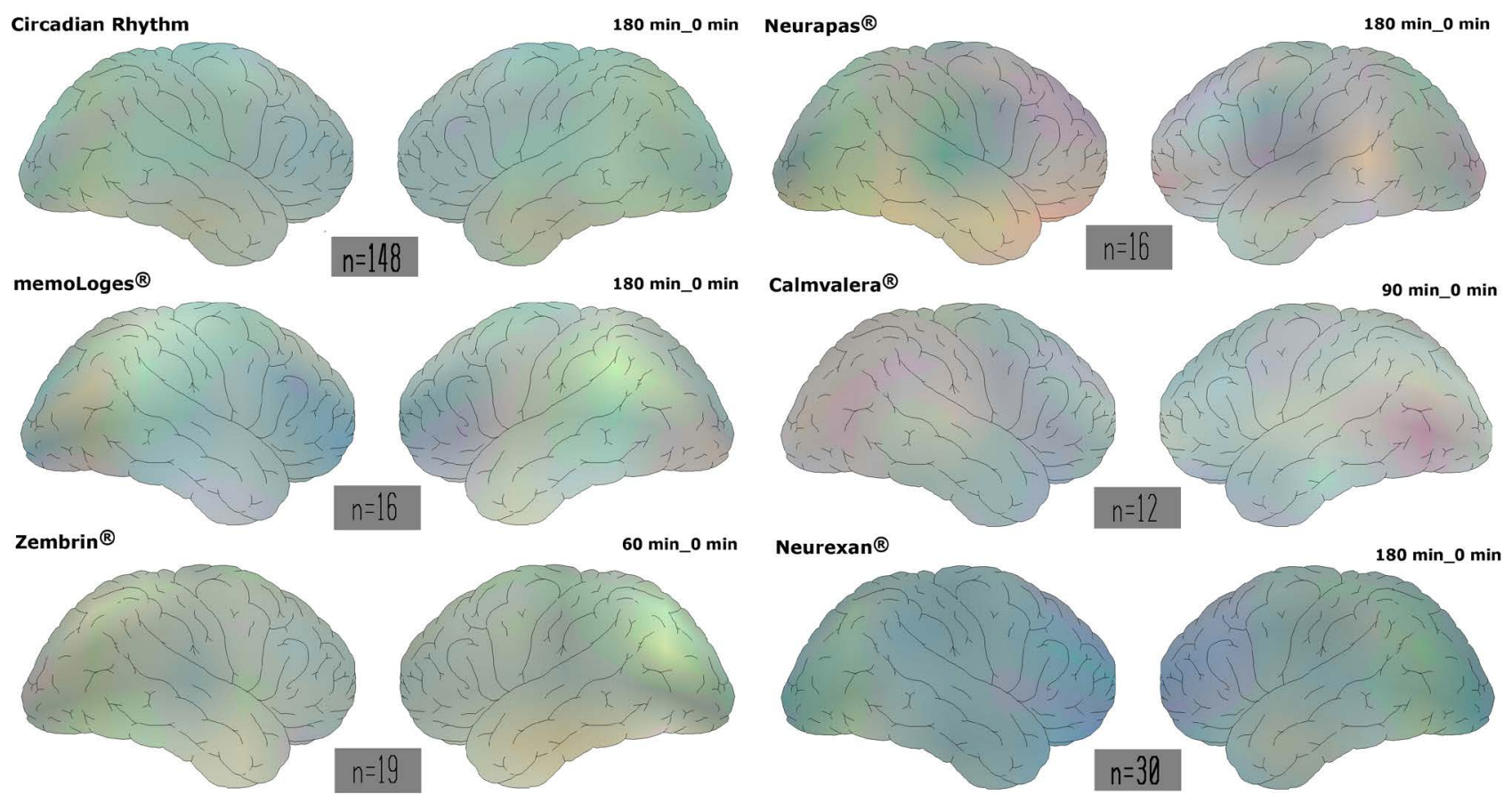

Figure 13. Documentation of drug effects by quantitative EEG in terms of brain mapping. Maps are constructed by transforming spectral power into spectral colours followed by additive colour mixture according to "RGB". (No false colour coding, but showing direct result of FFT!). Data are interpolated in a non-linear manner from 17 regions to give results for 99 channels in order to produce a map corresponding mathematically to a 64 channel EEG.

\section{Eyes Open}
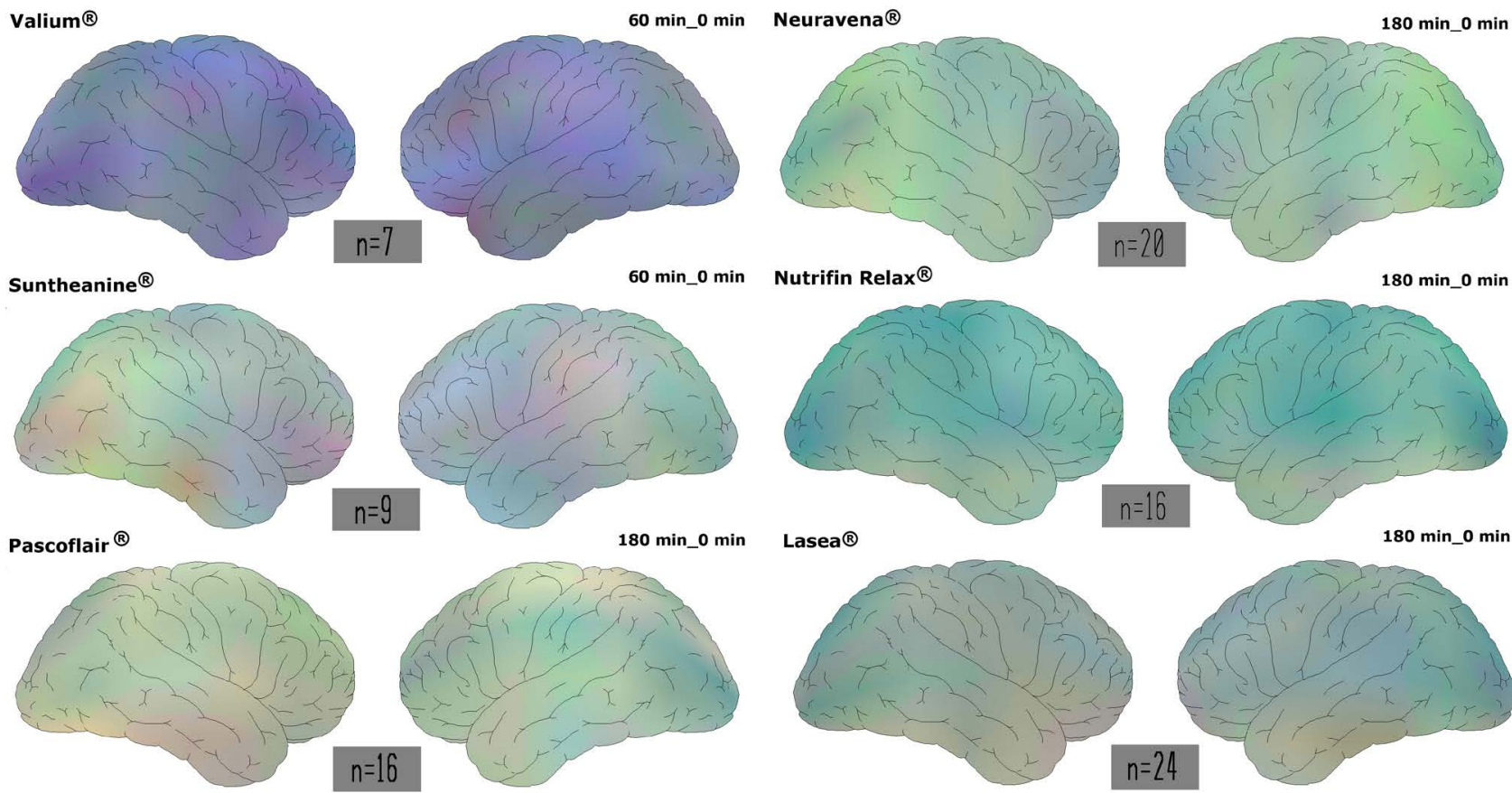

$180 \mathrm{~min} \_0 \mathrm{~min}$

Figure 14. Documentation of drug effects by quantitative EEG in terms of brain mapping. Maps are constructed by transforming spectral power into spectral colours followed by additive colour mixture according to "RGB". (No false colour coding, but showing direct result of FFT!). 


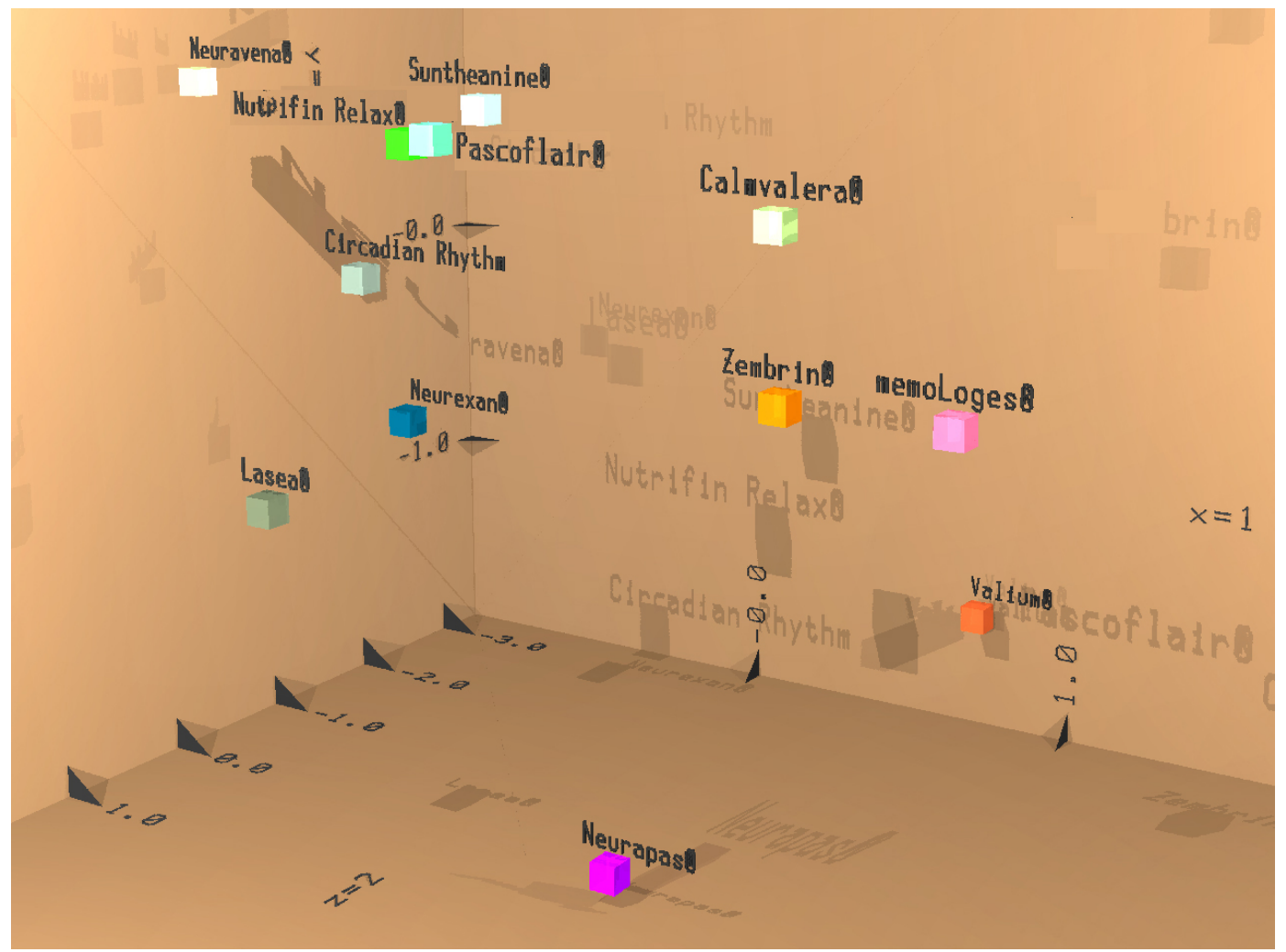

Figure 15. Result of discriminant analysis. Please note that the image is 6-dimensional! Result of first three discriminant functions is displayed in space (X; $\mathrm{Y}$ and $\mathrm{Z}$ axis). Result from next three discriminant functions is displayed according to additive colour mixture (so-called RGB). Neurapas ${ }^{\circledR}$ is positioned far in the foreground, Suntheanine ${ }^{\circledR}$ is positioned far in the background.

far away from the synthetic strongly sedative drug Valium ${ }^{\circledR}$. Two drugs acting positively on cognition $\left(\right.$ Zembrin $^{\circledR}$ and memoLoges ${ }^{\circledR}$ ) are not very far from each other, but show a different colour due to the result of the $4^{\text {th }}$ to $6^{\text {th }}$ discriminant function. Furthermore, the unique efficacy of Lasea ${ }^{\circledR}$ and Neurapas ${ }^{\circledR}$ is documented by their isolated position as shown in Figure 15.

\section{Discussion}

Quantitative EEG data have been used extensively to characterize drug effects on the brain in the past under the term Pharmaco-EEG [2]. However, direct comparison of several drugs with each other is only documented for single parameters like a particular frequency within a brain region. Recording of the EEG has been used successfully to compare different sedative drugs [27]. A pattern of frequency changes consisting of decreases of delta, theta and alpha activity in combination of strong increases of beta activity in the presence of Diazepam has been known for a long time as reported earlier [28]. Frequency changes observed in the freely moving rat correspond very much to those observed in humans as exemplified for Diazepam $\left(\right.$ Valium $\left.^{\circledR}\right)$ in Figure 16.

Individual patterns of frequency changes in the presence of different drugs also give hints on their mechanism of action since changes of particular frequencies 


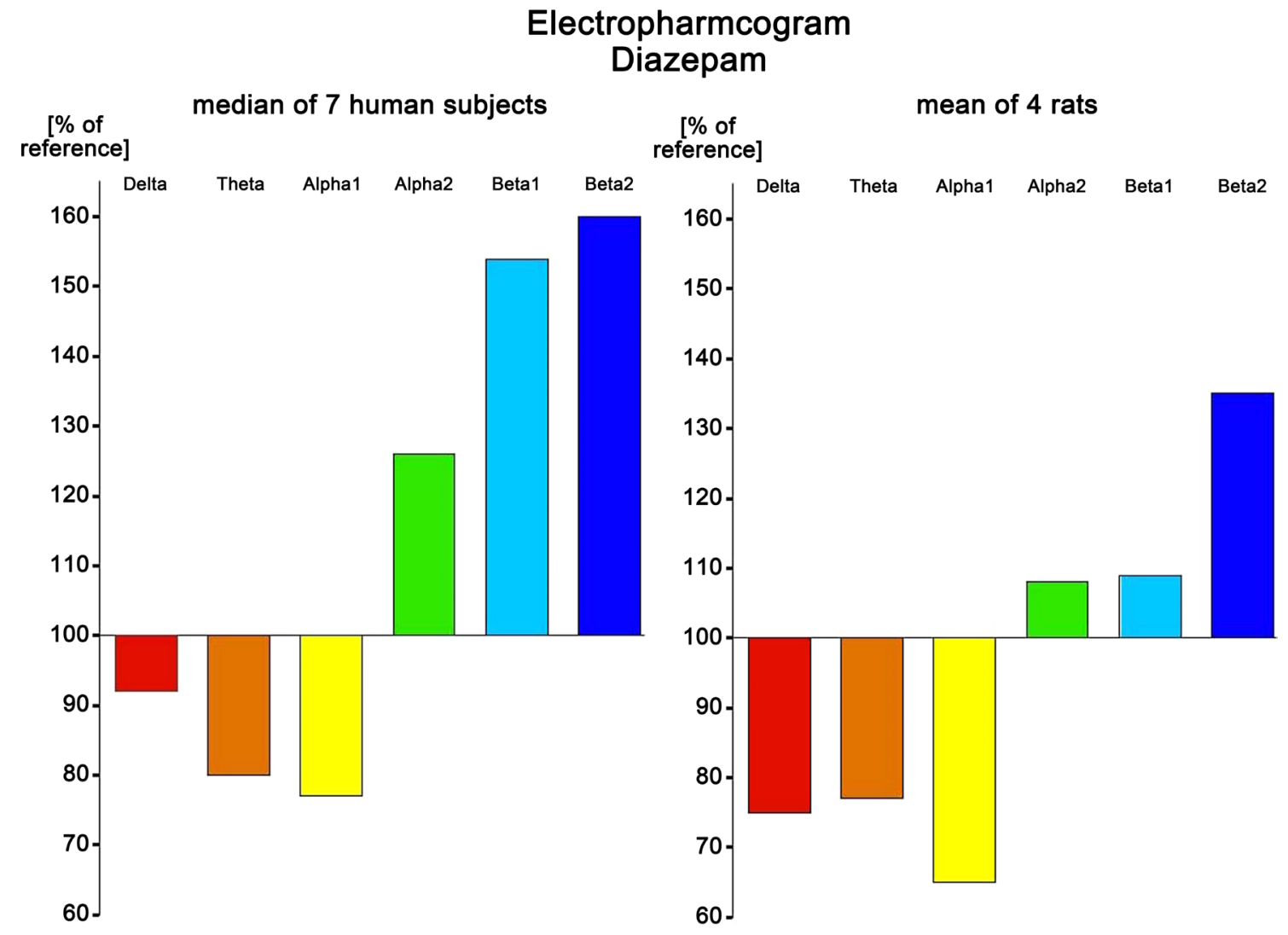

Figure 16. Comparison field potential analysis in the rat with quantitative EEG in humans for Diazepam (Valium $\left.{ }^{\circledR}\right)$.

have been related to neurotransmitter action. Extensive animal studies have revealed that delta waves are influenced by the activity of acetylcholine. Theta activity seems to be controlled by norepinephrine, whereas alpha 1 activity reflects serotonergic actions. Changes in dopaminergic activity are represented by alpha 2 spectral power [29]. Beta 1 waves are under the control of glutamate [30]. Finally, beta 2 waves change with the activity of GABA [31]. There is some indication that Pascoflair $^{\circledR}$ is able to modulate neuronal GABA receptor mediated transmission [32]. However, according to our data, beta 2 waves are not augmented in a statistically significant manner in the presence of Pascoflair ${ }^{\circledR}$. For the action of Valium ${ }^{\circledR}$ involvement of the GABA-ergic system has been proven [33] [34]. Accordingly, spectral power of beta 2 waves has increased.

A methodological approach is now presented, which allows evaluation of all experimental parameters at the same time: discriminant analysis [35]. Projection of the results from the first three discriminant functions into space already allows discrimination of drug action from each other. Regarding the result of next three mathematical discriminant functions (displayed by colour) allows even more detailed characterization of drug effects. If discriminant analysis is not able to separate the effects of different drugs from each other (being projected in close neighborhood), a similar clinical indication can be assumed. If the effect of a drug is projected in an isolated place, a unique indication might be suspected. Among the tested preparations this seems to be correct for Lasea ${ }^{\mathbb{B}}$ and Neurapas ${ }^{\mathbb{R}}$. 
After successful application in preclinical research [3] [36], the same approach has now been performed with human EEG data with regard to 11 herbal drugs in comparison to the synthetic classic Valium ${ }^{\circledR}$. As proven in the rat for analysis of quantitative field potentials, drugs acting on the human brain can now also be classified according to their overall effects on the brain.

\section{Conclusion}

In conclusion, discriminant analysis is not only used successfully in the pharmacological characterization of drug effects in rats, but proves to be a very convenient tool in describing the unique effects of herbal drugs in humans. This is a major progress and should be used in the future for characterization and classification of pharmacological effects of herbal drugs on the brain.

\section{Conflicts of Interest}

The author declares no conflicts of interest regarding the publication of this paper.

\section{References}

[1] Omenn, G.S. (1976) Neurochemistry and Behavior in Man (Medical Progress). Western Journal of Medicine, 125, 434-451.

[2] Jobert, M. and Wilson, F.J. (2015) Advanced Analysis of Pharmaco-EEG Data in Humans. Neuropsychobiology, 72, 165-177. https://doi.org/10.1159/000431096

[3] Dimpfel, W. (2003) Preclinical Data Base of Pharmaco-Specific Rat EEG Fingerprints (Tele-Stereo-EEG). European Journal of Medical Research, 8, 199-207.

[4] Dietsch, G. and Berger, H. (1932) Fourier-Analyse von Elektrencephalogrammen des Menschen. Pflüger's Archiv für die gesamte Physiologie des Menschen und der Tiere, 230, 106-112. https://doi.org/10.1007/BF01751972

[5] Harmony, T., Fernandez-Bouzas, A., Marosi, E., Fernandez, T., Bernal, J., Rodriguez, M., Reyes, A., Silva, J., Alonso, M. and Casian, G. (1993) Correlation between Computed Tomography and Voltage and Current Source Density Spectral Parameters in Patients with Brain Lesions. Electroencephalography and Clinical Neurophysiology, 87, 196-205. https://doi.org/10.1016/0013-4694(93)90019-R

[6] Dimpfel, W., Hofmann, H.C., Prohaska, A., Schober, F. and Schellenberg, R. (1996) Source Density Analysis of Functional Topographical EEG: Monitoring of Cognitive Drug Action. European Journal of Medical Research, 1, 283-290.

[7] Dimpfel, W., Todorova, A. and Vonderheid-Guth, B. (1999) Pharmadynamic Properties of St. John's Wort. A Single Blind Neurophysiological Study in Healthy Subjects Comparing Two Commercial Preparations. European Journal of Medical Research, 4, 303-312.

[8] Dimpfel, W., Schober, F. and Spüler, M. (1993) The Influence of Caffeine on Human EEG under Resting Conditions and during Mental Loads. The Clinical Investigator, 71, 197-207. https://doi.org/10.1007/BF00180102

[9] Cummings, L., Dane, A., Rhodes, J., Lynch, P. and Hughes, A.M. (2000) Diurnal Variation in the Quantitative EEG in Healthy Adult Volunteers. British Journal of Clinical Pharmacology, 50, 21-26. https://doi.org/10.1046/j.1365-2125.2000.00205.x

[10] Dimpfel, W., Tausend, S., Suliman, S. and Chiegoua Dipah, G.N. (2016) Psycho- 
physiological Effectiveness of Calmvalera Hevert Tablets as Measured by EnkephaloVision in Anxious Subjects during Audio-Visual Cognitive and Emotional Challenges: A Double-Blind, Randomized, Placebo-Controlled, 2-Armed, Phase IV Study in Parallel Design. Journal of Behavioral and Brain Science, 6, 404-431. https://doi.org/10.4236/jbbs.2016.610039

[11] Möller, H.-J., Volz, H.-P., Dienel, A., Schläfke, S. and Kasper, S. (2017) Efficacy of Silexan in Subthreshold Anxiety: Meta-Analysis of Randomised, Placebo-Controlled Trials. European Archives of Psychiatry and Clinical Neuroscience, 269, 183-193. https://doi.org/10.1007/s00406-017-0852-4

[12] Kasper, S., Müller, W.E., Volz, H.P., Möller, H.J., Koch, E. and Dienel, A. (2018) Silexan in Anxiety Disorders: Clinical Data and Pharmacological Background. The World Journal of Biological Psychiatry, 19, 412-420.

https://doi.org/10.1080/15622975.2017.1331046

[13] Dimpfel, W., Wedekind, W. and Dienel, A. (2015) Cerebral Bioavailability of Silexan-A Quantitative EEG Study in Healthy Volunteers. Open Journal of Psychiatry, 5, 285-297. https://doi.org/10.4236/ojpsych.2015.53032

[14] Dimpfel, W., Biller, A., Suliman, S. and Chiegoua Dipah, G.N. (2016) Psychophysiological Effects of a Combination of Sideritis and Bacopa Extract (memoLoges ${ }^{\mathbb{R}}$ ) in 32 Subjects Suffering from Mild Cognitive Impairment. A Double-Blind, Randomized, Placebo-Controlled, 2-Armed Study with Parallel Design. Advances in Alzheimer's Disease, 5, 103-125. https://doi.org/10.4236/aad.2016.53008

[15] Dimpfel, W., Schombert, L. and Biller, A. (2016) Psychophysiological Effects of Sideritis and Bacopa Extract and Three Combinations Thereof-A Quantitative EEG Study in Subjects Suffering from Mild Cognitive Impairment (MCI). Advances in Alzheimer's Disease, 5, 1-22. https://doi.org/10.4236/aad.2016.51001

[16] Dimpfel, W., Koch, K. and Weiss, G. (2011) Early Effect of Neurapas ${ }^{\circledR}$ Balance on Current Source Density (CSD) of Human EEG. BMC Psychiatry, 11, 123-138. https://doi.org/10.1186/1471-244X-11-123

[17] Dimpfel, W., Storni, C. and Verbruggen, M. (2011) Ingested Oat Herb Extract (Avena sativa) Changes EEG Spectral Frequencies in Healthy Subjects. The Journal of Alternative and Complementary Medicine, 17, 427-434. https://doi.org/10.1089/acm.2010.0143

[18] Kennedy, D.O., Jackson, P.A., Forster, J., Khan, J., Grothe, T., Perrinjaquet-Moccetti, T. and Haskell-Ramsay, C.F. (2017) Acute Effects of a Wild Green-Oat (Avena sativa) Extract on Cognitive Function in Middle-Aged Adults: A Double-Blind, Placebo-Controlled, Within-Subjects Trial. Nutritional Neuroscience, 20, 135-151. https://doi.org/10.1080/1028415X.2015.1101304

[19] Dimpfel, W. (2007) Psychophysiological Effects of Neurexan ${ }^{\circledR}$ on Stress-Induced Electropsychograms. A Double Blind, Randomized, Placebo-Controlled Study in Human Volunteers. 3rd Cell Stress Society International Congress on Stress Responses in Biology and Medicine and 2 nd World Conference of Stress (CSSI), Book of Abstracts, Budapest, Hungary, 23-26 August 2007, 16 A\#4 3B_01_P.

[20] Dimpfel, W., Pischel, I. and Lehnfeld, R. (2004) Effects of Lozenge Containing Lavender Oil, Extracts from Hops, Lemon Balm and Oat on Electrical Brain Activity of Volunteers. European Journal of Medical Research, 9, 423-431.

[21] Movafegh, A., Alizadeh, R., Hajimohamadi, F., Eshehani, F. and Nejatfar, M. (2008) Preoperative Oral Passiflora incarnata Reduces Anxiety in Ambulatory Surgery Patients: A Double-Blind, Placebo-Controlled Study. Anesthesia \& Analgesia, 106, 1728-1732. https://doi.org/10.1213/ane.0b013e318172c3f9 
[22] Dimpfel, W., Koch, K. and Weiss, G. (2012) Single Dose Effects of Pascoflair ${ }^{\circledR}$ on Current Source Density (CSD) of Human EEG. Neuroscience \& Medicine, 3, 130-140. https://doi.org/10.4236/nm.2012.32018

[23] Türközü, D. and Sanlier, N. (2017) L-Theanine, Unique Amino Acid of Tea, and Its Metabolism, Health Effects and Safety. Critical Reviews in Food Science and Nutrition, 57, 1681-1687. https://doi.org/10.1080/10408398.2015.1016141

[24] Friedman, H., Greenblatt, D.J., Peters, G.R., Metzler, C.M., Charlton, M.D., Harmatz, J.S., Antal, E.J., Sanborn, E.C. and Francom, S.F. (1992) Pharmacokinetics and Pharmacodynamics of Oral Diazepam: Effect of Dose, Plasma Concentration, and Time. Clinical Pharmacology \& Therapeutics, 52, 139-150. https://doi.org/10.1038/clpt.1992.123

[25] Chiu, S., Gericke, N., Farina-Woodbury, M., Badmaev, V., Raheb, H., Terpstra, K., Antongiorgi, J., Bureau, Y., Cernovsky, Z., Hou, J., Sanchez, V., Williams, M., Copen, J., Husni, M. and Goble, L. (2014) Proof-of-Concept Randomized Controlled Study of Cognition Effects of the Proprietary Extract Sceletium tortuosum (Zembrin) Targeting Phosphodiesterase- 4 in Cognitively Healthy Subjects: Implications for Alzheimer's Dementia. Evidence-Based Complementary and Alternative Medicine, 2014, Article ID: 682014. https://doi.org/10.1155/2014/682014

[26] Dimpfel, W., Gericke, N., Suliman, S. and Chiegoua Dipah, G.N. (2017) Effect of Zembrin $^{\circledR}$ on Brain Electrical Activity in 60 Older Subjects after 6 Weeks of Daily Intake. A Prospective, Randomized, Double-Blind, Placebo-Controlled, 3-Armed Study in a Parallel Design. World Journal of Neuroscience, 7, 140-171. https://doi.org/10.4236/wjns.2017.71011

[27] Golombok, S. and Lader, M. (1984) The Psychopharmacological Effects of Premazepam, Diazepam and Placebo in Healthy Human Subjects. British Journal of Clinical Pharmacology, 18, 127-133. https://doi.org/10.1111/j.1365-2125.1984.tb02444.x

[28] Nickel, B. and Szelenyi, I. (1989) Comparison of Changes in the EEG of Freely Moving Rats Induced by Enciprazine, Buspirone and Diazepam. Neuropharmacology, 28, 799-803. https://doi.org/10.1016/0028-3908(89)90170-6

[29] Dimpfel, W. (2008) Pharmacological Modulation of Dopaminergic Brain Activity and Its Reflection in Spectral Frequencies of the Rat Electropharmacogram. Neuropsychobiology, 58, 178-186. https://doi.org/10.1159/000191124

[30] Dimpfel, W. (2015) Drug Discovery and Translational Medicine. BoD-Books on demand, Norderstedt, Germany, 94.

[31] Christian, E.P., Snyder, D.H., Song, W., Gurley, D.A., Smolka, J., Maier, D.L., Ding, M., Gharahdaghi, F., Liu, X.F., Chopra, M., Ribadeneira, M., Chapdelaine, M.J., Dudley, A., Arriza, J.L., Maciag, C., Quirk, M.C. and Doherty, J.J. (2015) EEG- $\beta / \gamma$ Spectral Power Elevation in Rat: A Translatable Biomarker Elicited by $\mathrm{GABA}_{\mathrm{Aa} 2 / 3}$-Positive Allosteric Modulators at Nonsedating Anxiolytic Doses. Journal of Neurophysiology, 113, 116-131. https://doi.org/10.1152/jn.00539.2013

[32] Appel, K., Rose, T., Fiebich, B., Kammler, T., Hoffmann, C. and Weiss, G. (2011) Modulation of the Gamma-Aminobutyric Acid (GABA) System by Passiflora incarnata L. Phytotherapy Research, 25, 838-843. https://doi.org/10.1002/ptr.3352

[33] Yu, O., Chiu, T.H. and Rosenberg, H.C. (1988) Modulation of GABA-Gated Chloride Ion Flux in Rat Brain by Acute and Chronic Benzodiazepine Administration. Journal of Pharmacology and Experimental Therapeutics, 246, 107-113.

[34] Ferreri, M.C., Gutierrez, M.L. and Graviell, M.C. (2015) Tolerance to the Sedative and Anxiolytic Effects of Diazepam Is Associated with Different Alterations of GABAA Receptors in Rat Cerebral Cortex. Neuroscience, 310, 152-162. 
https://doi.org/10.1016/j.neuroscience.2015.09.038

[35] Smith, P.F. (2018) On the Application of Multivariate Statistical and Data Mining Analyses to Data in Neuroscience. The Journal of Undergraduate Neuroscience Education (JUNE), 16, R20-R32.

[36] Dimpfel, W. (2013) Pharmacological Classification of Herbal Extracts by Means of Comparison to Spectral EEG Signatures Induced by Synthetic Drugs in the Freely Moving Rat. Journal of Ethnopharmacology, 149, 583-589.

https://doi.org/10.1016/j.jep.2013.07.029 